Przesławska G., Rethinking economics in response to current crisis phenomena, „Ekonomia i Prawo. Economics and Law", Polszakiewicz B., Boehlke J. (ed.), Vol. 15, No. 1/2016, pp. 133-146. DOI: http://dx.doi.org/10.12775/EiP.2016.008.

\title{
RETHINKING ECONOMICS IN RESPONSE TO CURRENT CRISIS PHENOMENA ${ }^{\diamond}$
}

\author{
SUMMARY
}

In seven years from the eruption of a global economic crisis, a noticeable change has taken place in the approach of economists, as well as international economic organisations (i.e. IMF and the World Bank), to analysing the occurring crisis phenomena. A purpose of the article is to present transformation of views and positions of the abovementioned communities in the context of experiences in overcoming crisis and of the modern challenges of post-crisis economy. In this scope, the article shows changes in economic theory and policy and proposals for the new state role, especially emphasizing the significance of institutional environment for socio-economic development. The assumed research task, performed on the basis of a critical analysis of subject's literature, serves to verify an initial hypothesis of gradual formation of new rules of the game, i.e. institutional order, in the post-crisis world, of which Poland is a part. The postulated institutional order would constitute a connection of social, economic and political aspects. The analysis conducted in the article proved an influence of occurring crisis phenomena on evolution of economic science and policy. In this area, in order to increase explanatory and predictive power of macroeconomics, it is recommended to make use of a more heterodox approach which includes taking into account the financial markets' behavior and macroeconomic effects of income

" Gabriela Przesławska, University of Wrocław, Faculty of Law, Administration and Economics, Institute of Economic Science, ul. Uniwersytecka 22/26, 50-145 Wrocław, Poland, phone: + 48713752 358, e-mail: gabriela.przeslawska@uwr.edu.pl.

$\checkmark$ The article was funded by Faculty of Law, Administration and Economics at University of Wrocław. 
inequalities. In general, it can be stated that current revaluations in thinking about economy, although being the prerequisites for institutional change, are not of a breakthrough character, so they do not constitute critical junctures in economic development and theory. In this regard, the significance of governments' political will is emphasized as a basic factor in resolving problems resulting from global economic crisis. Keywords: crisis phenomena; lessons from economic crisis for economics and economic policy; socio-economic development; new role of the state; significance of institutional environment

JEL Classification: G01; E61; F60; F63; H11; O43

\section{INTRODUCTION}

The current economic crisis caused changes in modern economy and consequently - transformation of economic thinking. A problem which will be considered in the article concerns an extent to which the present crisis phenomena may be viewed as critical junctures in the evolution of the socio-economic system, thus constituting prerequisites for changing the existing rules of the game ${ }^{1}$.

A purpose of the article is to attempt to answer the following research questions:

- Do the crisis phenomena occurring in economy and the resulting changes in economic theory and policy have breakthrough character; are they, then, critical junctures in the development of economy and the theory of economics?

- Can we, using concepts and categories of institutional economics, speak about the occurring institutional change, or only about the emergence of prerequisites for change?

${ }^{1}$ By its own definition, crisis (Greek: krisis) is understood as a "deciding moment, breakthrough period” (J. Tokarski (ed.), Stownik wyrazów obcych, PWN, Warszawa 1980, p. 404, 523). Acemoglu and Robinson wrote that: "The notion of a critical juncture was first developed by Lipset and Rokkan (1967)". In their considerations on sources of power, luck and poverty, Acemoglu and Robinson define critical juncture as "major events that disrupt the existing political and economic balance in one or many societies" and "can cause a sharp turn in the trajectory of a nation" (D. Acemoglu, J.A. Robinson, Why Nations Fail: The Origins of Power, Prosperity, and Power, Crown, New York 2012, p. 431; S.M. Lipset, S. Rokkan (eds.), Party System and Voter Alignments, Free Press, New York 1967). 


\section{THE CURRENT STATE OF KNOWLEDGE}

\subsection{CRISIS PHENOMENA IN ECONOMY AND ECONOMIC SCIENCE}

The literature concerning reasons and nature of current crisis phenomena is immeasurably rich. This subject was dealt with by i.a. the Nobel Prize in economy laureates: Joseph Stiglitz ${ }^{2}$, Paul Krugman ${ }^{3}$ as well as Nouriel Roubini and Stephen Mihm ${ }^{4}$. In Polish economic literature, the problems connected with crisis and these concerning the post-crisis state of economics were considered by many notable economists, i.a. Elżbieta Mączyńska, Marek Belka, Bogusław Fiedor, Grzegorz Kołodko, Marek Ratajczak, Andrzej Wojtyna ${ }^{5}$.

In subject's literature, it is accepted that crisis phenomena are unfavorable tendencies in world economy. Besides crisis phenomena occurring in economy, both in real and regulational sphere, there's also a talk about the occurrence of such phenomena in economic science, from the viewpoint of the scientific (cognitive) realism and the application criteria ${ }^{6}$.

Putting the idea synthetically, Kołodko views the recent crisis as a result of "many political, social and economic, as well as technological, circumstances. Coincidence of these conditions in a specific way, resulting in accumulation of occurrences and processes likely to cause crises, was possible only in the case of the combination of values, institutions and politics which is typical for neoliberalism" 7 .

2 J.E. Stiglitz, Freefall. Jazda bez trzymanki. Ameryka, wolne rynki i tonięcie gospodarki amerykańskiej, PTE, Warszawa 2010.

${ }^{3}$ P. Krugman, Zakończcie ten kryzys!, Helion, Gliwice 2013.

${ }^{4}$ N. Roubini, S. Mihm, Ekonomia kryzysu, Wolters Kluwer business, Warszawa 2011.

5 The problems related to the $2007+$ crisis were discussed at the Plenary Session of the $9^{\text {th }}$ Congress of Polish Economists. The papers of most of the mentioned authors, concerned with crisis in economy and in economic theory, are included in the following publication: E. Mączyńska (ed.), Ekonomia dla przysztości. Fundamentalne problemy teorii ekonomii i praktyki gospodarczej, PTE, Warszawa 2014.

${ }^{6}$ B. Fiedor, Kryzys gospodarczy a kryzys ekonomii jako nauki, "Ekonomista", No. 4/2010, p. 453 and next; J. Godłów-Legiędź, Wspótczesna ekonomia. Ku nowemu paradygmatowi, C.H. Beck, Warszawa 2010, pp. 168-170. On this subject also: G. Przesławska, Ekonomia w czasach kryzysu, [in:] J. Kundera (ed.), Globalizacja, europejska integracja a kryzys gospodarc$z y$, Instytut Nauk Ekonomicznych Wydziału Prawa, Administracji i Ekonomii Uniwersytetu Wrocławskiego, Wrocław 2011, pp.171-184.

${ }^{7}$ G. Kołodko, Neoliberalizm i światowy kryzys gospodarczy, "Ekonomista", No. 1/2010, pp.121-122. 
The biggest problems of modern world, according to E. Mączyńska, are "the global imbalance, increasing symptoms of socio-economic disorder and rising impermanence in economy". Similarly to aforementioned authors, she states that the sources of these occurrences are theoretical monism and doctrinalization, manifesting themselves in the domination of neoliberal doctrine since 1970s, together with the applicable axiom of reliability and effectiveness of the market. For these reasons, she sees the need for adjusting the socio-economic system model to the challenges of happening civilization breakthrough. In her opinion, preferences typical for neoliberal socio-economic systems require revaluation ${ }^{8}$.

\subsection{INSTITUTIONAL CHANGE - NATURE, SOURCES, FACTORS OF CHANGES}

Understanding the nature of economic changes which are also regarded as institutional changes is a contribution of a Nobel laureate Douglass Cecil North ${ }^{9}$. Presenting a vision of a pro-development institutional order in the scope of economic, political and social changes, he extends the theory of new institutional economy, claiming the necessity of "a fundamental recasting of the way we think"10. He abandons the paradigm of neoclassical theory, at the same time expressing doubt whether in the process of creating a dynamic theory of change, a coherence comparable with this of the general equilibrium theory will be ensured ${ }^{11}$.

As a basic change factor, he views institutions, which constitute motivational structure of changes, whose sources are social environment and its interpretation by members of the society. For this reason, institutional change is a result of cultural evolution governed by perception and, particularly, intentionality of players ${ }^{12}$. According to North, the possible sources of changes in institutions are challenges from surrounding environment, which induce change in views on new possibilities and new choices. New challenges cause

${ }^{8}$ E. Mączyńska, Wspótczesne wyznaczniki przemian w systemach spoteczno-gospodarczych, [in:] M. Bucka, Z. Mikołajewicz (eds.), Procesy gospodarczego i spotecznego rozwoju wobec wyzwań wspótczesnego świata, Wydawnictwo Uniwersytetu Opolskiego, Opole 2014, pp. 21-37.

9 D.C.North, Understanding the Process of Economic Change, Princeton University Press, Princeton 2005, p. XVII.

${ }^{10}$ Ibidem, p. VII.

11 Ibidem, p. XVII.

${ }^{12}$ Ibidem, pp. XVIII-XIX. 
a gradual change of rules of the game, creating new limitations to processes of interaction ${ }^{13}$.

According to Daron Acemoglu and James Robinson, representatives of political economy of development, the most important purpose of management and a condition for prosperity of the nations is the economic growth. The important determinants of growth, besides factors confirmed in theoretical and empirical research, such as: capital, human capital and technologies, are also institutions created by society and policies generating stimuli to innovation, reallocation, investment and education. In accordance with Acemoglu's and Robinson's thinking direction, a main factor which could enable solution to present problems connected with economic crisis is the political will of modern world's governments. They view poverty and global inequalities as problems of development ${ }^{14}$.

This point of view corresponds with the approach of D. North, who recognizes the role of political system - and not economy on its own - in adaptation of system in conditions of uncertainty, which will take place through elimination of ineffective solutions (whose durability is useful to interest groups) and formation of a more flexible institutional structure.

At the same time, North points out that in a non-ergodic world it is hard to "create polities that will put in place economic rules with the correct incentives" 15 .

This means that the crisis phenomena, both in economy and in economic science, should be considered a source of institutional change with its characteristic indications, i.e. inertion of institutions, limited rationality of "players in the game" - institutional changes agents, "history dependence", collective actions problem, existence of political entrepreneurs, complementarity of institutions, which causes "resistance" of institutions to change ${ }^{16}$.

Research in discussed scope indicates that: "in the process of institutional changes, political factors are particularly significant, including the activity of public or private actors, because of the strong ability to coordinate and involve considerable means"17.

${ }^{13}$ W. Stankiewicz, Ekonomika instytucjonalna. Zarys wyktadu, Wydawnictwo Prywatnej Wyższej Szkoły Businessu i Administracji, Warszawa 2005, p. 110.

${ }^{14}$ D. Acemoglu, J.A. Robinson, op. cit., Crown, New York 2012, p. 56.

15 D.C. North, op. cit., p. 177.

${ }^{16}$ C. Kingston, G. Caballero, Comparing Theories of Institutional Change, "Journal of Institutional Economics”, Vol. 5, No. 02/2009, pp. 151-180.

${ }_{17}$ Opinion of Kathleen Thelen, Professor at the Massachussets Institute of Technology in: M. Lissowska, Institutions that Change the World, "Gospodarka Narodowa", No. 6/2014, pp. 189-190. 
The abovementioned conditions cause that - as North pointed out changes of institutions in free society take usually place gradually and are mainly of incremental character ${ }^{18}$.

\section{THE METHODOLOGY OF RESEARCH}

The assumed research task, emphasizing the evolutionary character of changes, including these related to the development of economic science and policy, as well as the significance of institutional, cultural, social and political aspects in designing institutional order, are reasons for which in the analysis conducted in the article, a viewpoint of institutional economics, including political economy of development, is also considered. As a research method, critical analysis of subject's literature is employed. The applied method involves logical analysis, as well as the analysis of cause-effect relationships concerning the influence of state's intervention on reducing crisis phenomena. Because of the choice of discussed issues, the analyzed content is approached in a holistic manner and widely includes judgments of postulative and normative character. Due to the influence of occurring crisis phenomena and the necessity of more realistic approach to economic phenomena, the subject's literature contains views claiming the need of methodological equilibrium in economics, i.e. equivalence of positive and normative judgments ${ }^{19}$.

\section{THE RESEARCH PROCESS}

\subsection{POST-CRISIS CHANGES IN ECONOMIC THEORY AND POLICY}

Ricardo Caballero agrees with the opinion that the last financial crisis challenged the credibility of macroeconomics due to its inability to predict crisis. As a main problem of academic macroeconomics, he views contradiction between the vast complexity of its subject and attempting microeconomic precision. This state of affairs resulted in main problems of present crisis, i.a. such as: cycles based on leveraging, speculative bubbles, "infection" phenomenon, liquidity crises, security of deposits, were explained in the so-called

${ }_{18}$ D.C.North, op. cit., p. 3, 6.

19 B. Fiedor, Uwagi o potrzebie równowagi metodologicznej w ekonomii, "Studia Ekonomiczne", No. 1/2013, pp. 110-114. 
"periphery" (and not main core of the macroeconomics) and became the basis for policy applied during crisis $^{20}$.

Seven years after the eruption of crisis, Oliver Landman assesses the state of economics. He notes that the 2008 crisis, resulting in current recession, hasn't caused a breakthrough in macroeconomics. The paradigm of new neoclassical synthesis (NNS), which created a framework for short-run macro analysis, hasn't grasped the key elements of recent crisis, particularly the financial market disruptions. Although the pre-crisis consensus in macroeconomics was shaken according to Landmann, there are no existing indications of emergence of a new paradigm which could change the beliefs of the whole generation of economists, which has taken place twice in the 20th century (1930s - Keynesian revolution and 1970s - neoclassical revolution). The crisis also hasn't caused change in methodology of scientific research specific for NNS. This methodology is still based on the presumption, that all macroeconomic theories should have rigorous macroeconomic justification. In Landman's opinion, it was such analyzing of macroeconomic phenomena based on microeconomic foundations that resulted in undervaluing the problems constituting sources of 2008 financial crisis, i.a. imperfect information and disruptions in coordination ${ }^{21}$.

Alan Blinder, in a paper presented in 2014 on an annual meeting of the American Economic Association, drew conclusions from the recent crisis for economic policy and teaching economics. He stated that the aid programmes known jointly as "quantitative easing", approved by Congress, Department of the Treasury and Federal Reserve, were the widest package of interventionist economic policy in USA since the war in the 1940s. Instruments of Keynesian economics, i.e. measures of monetary policy (lower interest rates, increased money creation) and fiscal policy (lowering the taxes, increasing expenditures), were applied during crisis all over the world for the purpose of stimulation of economy ${ }^{22}$. The taken actions haven't led to revolution (breakthrough) in economic thinking similar to the one from 1930. An example of changes in economics is a renewed relevance of Hyman Minsky's

${ }^{20}$ R. Caballero, Macroeconomics after the Crisis: Time to Deal with the Pretense - of Knowledge Syndrome, "Journal of Economic Perspectives", Vol. 24, No. 4/2010, p. 85-102. On this subject: A. Wojtyna, Czy kryzys w teorii ekonomii jest gtębszy niż w gospodarce?, "Ekonomista", No. 2/2014, pp. 194-195.

${ }^{21}$ O Landmann, Short-Run Macro After the Crisis: The End of the "New" Neoclassical Synthesis?, "University of Freiburg Discussion Paper Series”, No. 27/2014, https://www.macro.uni-freiburg. de/publications/research_articles_landmann (07.10.2015), pp. 1-22.

22 A. Blinder, What Did We Learn from the Financial Crisis, the Great Recession, and the Pathetic Recovery?, “The Journal of Economic Education”, Vol. 46, No. 2/2015, pp. 4-5. 
work and the institutional changes, i.e. establishment of Financial Stability Oversight Council for the prevention of systematic risk and the Consumer Financial Protection Bureau for the protection of consumers from financial problems, and the changes implemented by the 2010 Dodd-Frank Act. Blinder emphasizes the role of proper economic education in preventing crises. According to him, it was lack in education which resulted in cases of abuse on financial market. An example of this was elites' disregard of the rule which says that when unemployment is high, the government spending multiplier is positive, which means that the purpose of fiscal expansion is to make recession shorter. In Blinder's opinion, this rule shouldn't be associated with specific political views, because Keynesianism is neither conservative nor liberal ${ }^{23}$.

This situation could be summed up as follows: although there are visible signs of leading universities opening themselves to new ideas, A. Wojtyna states that "institutional framework of conducting research and publishing its results, as well as resulting stimuli, which the scientists follow, are, however, characterized by very large inertness" 24 .

\subsection{EVOLUTION OF VIEWS OF THE INTERNATIONAL MONETARY FUNDS RESEARCHERS}

The crisis caused change in previously orthodox IMF's views, which manifested itself "in official doctrine, aid programmes and indications for "effective macroeconomic and macroprudential policy" 25 . IMF is no longer considered to be a guardian and supporter of the Washington consensus, but its critic $^{26}$. Analysis of IMF researchers views on the problem of fiscal consolidation shows the evolution of IMF's approach. The commonly recognized before the crisis idea that expansive consolidation of expense-cutting, i.e. limiting fiscal deficit through higher taxes and particularly through cutting expenditures, is a way to generate economic growth, isn't as widely accepted today. Studies conducted in recent years indicate that sudden fiscal consolidation leads to decrease in national demand and lower GDP, and a slower growth causes higher public debt in relation to $\mathrm{GDP}^{27}$. Recent crisis related to lower level of economic activity also sparked discussions in IMF on ways of encourag-

${ }^{23}$ Ibidem, p. 16.

${ }^{24}$ A.Wojtyna, op. cit., pp. 199-200.

${ }^{25}$ Ibidem, p. 194.

${ }^{26}$ Stasiński M., Marek Belka: Skończmy z kapitalizmem wyczynowym, "Gazeta Wyborcza", 18-19.07.2015, http://wyborcza.pl/magazyn/1,146875,18384078,marek-belka-skonczmy-z-kapitalizmem-wyczynowym.html (07.10.2015).

27 D.M. Nuti, Polityka oszczędnościowa a rozwój, [in:] G.W. Kołodko (ed.), Zarzadzanie i polityka gospodarcza dla rozwoju, Poltext, Warszawa 2014, pp. 296-299. 
ing growth. Attention was paid to relations between fiscal inequalities, crises and durability of growth. In particular, there was an intensification of studies on dependencies between inequalities, income distribution and economic growth, which were recognized as more complex than they had been considered to be ${ }^{28}$. The IMF researchers admit that although inequalities, creating incentives for growth, are an effective element of functioning of market economy, too large inequalities may be harmful for growth. In their opinion, inequalities create higher potential for financial crisis, foster political instability, discourage investing and make access to education and economic activity harder for the poor.

Facing crisis effects, i.e. low growth potential and high unemployment, IMF presented proposals of reforms on labour market. As a desired direction of labour market institutions reforms, it is recommended to widespread the Scandinavian model (flexicurity), whose elements are: flexible labour market, ensuring not only growth but also securing employees' interests, and another important element, i.e. creating a climate of trust between firms and employees $^{29}$. As Christine Lagarde, the Managing Director (MD) of the IMF, states, a new post-crisis economic consensus must be aimed at promoting both larger equality and greater efficiency.In this scope, the postulated changes in the rules of the game are supposed to protect workers' interests more than jobs. The new institutional solutions are: appropriate minimum wage level, policies which facilitate seeking for jobs matching skills and - following the example of Scandinavian countries - unemployment insurance ${ }^{30}$.

\subsection{NEW ROLE OF STATE IN ECONOMY. CHANGE IN THE IDEOLOGICAL CLIMATE IN POLAND}

As a breakthrough sign in economic thinking, the book by Mariana Mazzucato, Professor in Economics of Innovation at the University of Sussex, entitled The Entrepreneurial State. Debunking Public vs. Private Sector Myths is recognized. This work was singled out by "Financial Times" and many influential economists (i.a. Dani Rodrik, Professor of International Political Economy at Harvard University's John F. Kennedy School of Government)

${ }^{28}$ C. Lagarde, Lifting the Small Boats, https://www.imf.org/external/np/speeches/2015/061715. htm (07.10.2015); A.G. Berg, J.D. Ostry, Inequality and Unsustainable Growth: Two Sides of the Same Coin?, "IMF Staff Discussion Notes", Vol. 11, No. 08/2011.

${ }^{29}$ O. Blanchard, F. Jaumotte, P. Loungani, Labor Market Policies and IMF Advice in Advanced Economies During the Great Recession, "IMF Staff Discussion Notes", Vol. 13, No. 02/2013.

${ }^{30}$ C. Lagarde, op.cit. 
as one of the most important books from 2013. The author in an innovative way highlighted the significance of active government not only in creating markets and decreasing its failures, but above all in encouraging innovations in private sector, thus generating economic growth ${ }^{31}$.

Proposals to build an "innovation state" are also presented by the already quoted Dani Rodrik, in whose opinion such state could play a similar role in stabilizing capitalism in the $21^{\text {st }}$ century as welfare state did in the $20^{\text {th }}$ century. Success of a new approach, i.e. one taking into account the social dimension of technological innovations, depends, according to him, mainly on political and institutional decisions ${ }^{32}$. In this context, Vito Tanzi, the Honorary President of the International Institute of Public Finance and the Director of the Fiscal Affairs Department of the IMF from 1981 to 2000, writing about relations between fiscal policy, entrepreneurship and fair growth, emphasizes that although growth in economy is ensured by businesses, it is the government that sets rules of the game in market economy, i.e. regulations in the scope of use of resources, labor and capital. For this reason, he considers partnership between government and entrepreneurs essential, highlighting the difficulty in establishing the proper scope of governments' intervention. As he points out, debate on this matter belongs to sphere of "normative" economics and economic policy ${ }^{33}$.

The crisis phenomena analyzed in the article caused present changes in ideological climate in Poland and questioning of previous beliefs ${ }^{34}$. Authors of the report Cultural reform 2020-2030-2040. Success requires changes ${ }^{35}$ point out that in Poland the possibilities to create innovative economy basing on standard approaches have also run out. In the pictured vision of the chang-

${ }^{31}$ M. Mazzucato, The Entrepreneurial State. Debunking Public vs. Private Sector Myths, Anthem Press, London, New York 2013. On this subject: D. Rodrik, From Welfare State to Innovation State, https://www.project-syndicate.org/commentary/labor-saving-technology-by-dani-rodrik2015-01?barrier=true (07.10.2015); R. Woś, Więcej państwa proszę!, http://www.obserwatorfinansowy.pl/tematyka/makroekonomia/wiecej-panstwa-prosze (07.10.2015); G. Przesławska, Pokryzysowa rola państwa w gospodarce - nowe kierunki badań podstawowe dylematy, "Polityka Gospodarcza”, No. 22/2014, pp.119-139.

${ }^{32}$ D. Rodrik, op. cit.

${ }^{33}$ V. Tanzi, Polityka fiskalna na rzecz przedsiębiorczości i sprawiedliwego wzrostu, [in:] G.W. Kołodko (ed.), Zarzadzanie i polityka gospodarcza dla rozwoju, Poltext, Warszawa 2014, pp. 271-290.

${ }^{34}$ G. Sroczyński, Jak pieniadze pustoszq nasz świat, "Gazeta Wyborcza”, 04.04.2015, http://wyborcza.pl/magazyn/1,144507,17699870,Jak_pieniadze_pustosza_nasz_swiat.html (07.10.2015).

35 J. Żakowski (ed.), Reforma kulturowa 2020-2030-2040. Sukces wymaga zmian, http://www. kig.pl/files/Aktualnosci/KIG_RAPORT.pdf (07.10.2015), pp. 1-98. 
es, the sources of innovative growth are "essential changes in mentality and culture, stances and social relations connecting us". The named present challenges requiring changes, or even cultural revolution, include demographical crisis, cheap labour trap, middle income trap, secular stagnation, crisis of innovation, low level of social capital and disturbance of social balance related to income fragmentation ${ }^{36}$.

In the scope of discussion on reforms in teaching economics, Marek Ratajczak argues that it is essential to take into account the variableness of economic world and the evolutionary nature (particularly of cultural character) of economic phenomena. In this context, he also sees the need of new understanding of state's role in economy, not only as an alternative to the market, but also as an institution which regulates and secures from "abuse of economic power for the pursuit of particular interests" 37 .

\section{CONCLUSIONS}

In response to a research question formulated in the article, concerning the nature of changes of the "rules of the game", i.e. institutions, influenced by present crisis, the following conclusions may be found. The character of present debate of economists does not indicate shifts in Kuhn sense having taken place in paradigm of economics. What has occurred was rather the attempts to reconstruct theory in Lakatos understanding because basic ideas and rules of the core haven't changed; only certain elements of protective belt, i.e. economic practice, have ${ }^{38}$. Crisis also hasn't caused change in methodology of economic research specific for New Neoclassical Synthesis. This methodology is still based on a presumption that all macroeconomic theories should have rigorous microeconomic justification. Such situation is a consequence

36 E. Mączyńska, Inkluzywna gospodarka, [in:] J. Żakowski (ed.), Reforma kulturowa 20202030-2040. Sukces wymaga zmian, http://www.kig.pl/files/Aktualnosci/KIG_RAPORT.pdf (07.10.2015), p. 7; E. Mączyńska, Sekularna stagnacja, [in:] J. Żakowski (ed.), Reforma kulturowa 2020-2030-2040. Sukces wymaga zmian, http://www.kig.pl/files/Aktualnosci/KIG_ RAPORT.pdf (07.10.2015), p. 21, 82.

${ }^{37}$ M. Ratajczak, Ekonomia i edukacja ekonomiczna w dobie finansyzacji, [in:] E. Mączyńska (ed.), Ekonomia dla przysztości. Fundamentalne problemy w teorii ekonomii i praktyce gospodarczej, PTE, Warszawa 2014, s. 114.

38 P. Spiegler, W. Milberg, Methodenstreit 2011? Historical Perspective on the Contemporary Debate Over How to Reform Economics, "Forum for Social Economics", Vol. 42, No. 4/2013, pp. 311-345. 
of "path dependence", i.e. a pattern of theory's evolution as well as of the evolution of real economy.

It means that the present crisis phenomena haven't become critical junctures in the evolution of economics and economic policy.

At the same time, one should notice the symptoms of new way of thinking about the role of state in economy and the significance of its regulatory functions, particularly in designing a pro-development institutional order. In this sense, economists claim the necessity to consider holistic approaches and balance of positive and normative judgements in explaining crisis phenomena. Evolution of IMF's researchers' views on the dependence between fiscal consolidation and growth, inequalities, income distribution and economic growth, as well as concerning the desired reforms on labour market, allows to speak about the appearance of indications of inclusive growth and sustainable development purposes being shaped in IMF strategies. A need to design new, pro-development institutional order is argued also in Poland. The core of new socio-economic order would involve essential cultural changes and regaining social balance.

\section{BIBLIOGRAPHY}

Acemoglu D., Robinson J.A, Why Nations Fail: The Origins of Power, Prosperity, and Power, Crown, New York 2012.

Berg A.G., Ostry J.D, Inequality and Unsustainable Growth: Two Sides of the Same Coin?, "IMF Staff Discussion Notes", Vol. 11, No. 08/2011, http://dx.doi. org/10.5089/9781463926564.006.

Blanchard O., Jaumotte F., Loungani P., Labor Market Policies and IMF Advice in Advanced Economies During the Great Recession, "IMF Staff Discussion Notes", Vol. 13, No. 02/2013, http://dx.doi.org/10.5089/9781484301289.006.

Blinder A., What Did We Learn from the Financial Crisis, the Great Recession, and the Pathetic Recovery? "The Journal of Economic Education", Vol. 46, No. 2/2015, http://dx.doi.org/10.1080/00220485.2015.1015190.

Caballero R., Macroeconomics after the Crisis: Time to Deal with the Pretense - of Knowledge Syndrome, "Journal of Economic Perspectives", Vol. 24, No. 4/2010, http://dx.doi.org/10.1257/jep.24.4.85.

Fiedor B., Kryzys gospodarczy a kryzys ekonomii jako nauki, "Ekonomista", No. 4/2010.

Fiedor B., Uwagi o potrzebie równowagi metodologicznej w ekonomii, "Studia Ekonomiczne", No. 1/2013.

Godłów-Legiędź J., Wspótczesna ekonomia. Ku norvemu paradygmatowi, C.H. Beck, Warszawa 2010. 
Kingston C., Caballero G., Comparing Theories of Institutional Change, "Journal of Institutional Economics", Vol. 5, No. 02/2009, http://dx.doi.org/10.1017/ s1744137409001283.

Kołodko G.W., Neoliberalizm i światowy kryzys gospodarczy, "Ekonomista”, No. 1/2010. Krugman P., Zakończcie ten kryzys!, Helion, Gliwice 2013.

Lagarde C., Lifting the Small Boats, https://www.imf.org/external/np/speeches/2015/061715.htm (07.10.2015).

Landmann O., Short-Run Macro After the Crisis: The End of the "New" Neoclassical Synthesis?, "University of Freiburg Discussion Paper Series", No. 27/2014, https://www.macro.uni-freiburg.de/publications/research_articles_landmann (07.10.2015).

Lipset S.M., Rokkan S.(eds.), Party System and Voter Alignments, Free Press, New York 1967.

Lissowska M., Institutions that Change the World, "Gospodarka Narodowa", No. 6/2014.

Mączyńska E. (ed.), Ekonomia dla przysztości. Fundamentalne problemy teorii ekonomii i praktyki gospodarczej, PTE, Warszawa 2014.

Mączyńska E., Wspótczesne wyznaczniki przemian w systemach spoteczno-gospodarczych, [in:] M. Bucka, Z. Mikołajewicz (eds.), Procesy gospodarczego i spotecznego rozwoju wobec wyzwań wspótczesnego świata, Wydawnictwo Uniwersytetu Opolskiego, Opole 2014.

Mazzucato M., The Entrepreneurial State. Debunking Public vs. Private Sector Myths, Anthem Press, London, New York 2013.

North D.C., Understanding the Process of Economic Change, Princeton University Press, Princeton 2005.

Nuti D.M., Polityka oszczędnościowa a rozwój, [in:] G.W. Kołodko (ed.), Zarzqdzanie i polityka gospodarcza dla rozwoju, Poltext, Warszawa 2014.

Przesławska G., Ekonomia w czasach kryzysu, [in:] J. Kundera (ed.), Globalizacja, europejska integracja a kryzys gospodarczy, Instytut Nauk Ekonomicznych Wydziału Prawa, Administracji i Ekonomii Uniwersytetu Wrocławskiego, Wrocław 2011.

Przesławska G., Pokryzysowa rola państwa w gospodarce - nowe kierunki badań podstaworve dylematy, "Polityka Gospodarcza”, No. 22/2014.

Ratajczak M., Ekonomia i edukacja ekonomiczna w dobie finansyzacji, [in:] E. Mączyńska (ed.), Ekonomia dla przysztości. Fundamentalne problemy w teorii ekonomii i praktyce gospodarczej, PTE, Warszawa 2014.

Rodrik D., From Welfare State to Innovation State, https://www.project-syndicate. org/commentary/labor-saving-technology-by-dani-rodrik-2015-01?barrier=true (07.10.2015).

Roubini N., Mihm S., Ekonomia kryzysu, Wolters Kluwer, Warszawa 2011.

Spiegler P., Milberg W., Methodenstreit 2011? Historical Perspective on the Contemporary Debate Over How to Reform Economics, "Forum for Social Economics", Vol. 42, No. 4/2013, http://dx.doi.org/10.1080/07360932.2013.814089. 
Sroczyński G., Jak pieniądze pustoszq nasz śrwiat, "Gazeta Wyborcza”, 04.04.2015, http://wyborcza.pl/magazyn/1,144507,17699870,Jak_pieniadze_pustosza_nasz_ swiat.html (07.10.2015).

Stankiewicz W., Ekonomika instytucjonalna. Zarys wyktadu, Wydawnictwo Prywatnej Wyższej Szkoły Businessu i Administracji, Warszawa 2005.

Stasiński M., Marek Belka: Skończmy z kapitalizmem wyczynowym, "Gazeta Wyborcza”, 18-19.07.2015, http://wyborcza.p1/magazyn/1,146875,18384078, marek-belka-skonczmy-z-kapitalizmem-wyczynowym.html (07.10.2015).

Stiglitz J.E., Freefall. Jazda bez trzymanki. Ameryka, wolne rynki i tonięcie gospodarki amerykańskiej, PTE, Warszawa 2010.

Tanzi V., Polityka fiskalna na rzecz przedsiębiorczości i sprawiedliwego wzrostu, [in:] G.W. Kołodko (ed.), Zarzqdzanie i polityka gospodarcza dla rozwoju, Poltext, Warszawa 2014.

Tokarski J. (ed.), Stownik wyrazów obcych, PWN, Warszawa 1980.

Wojtyna A., Czy kryzys w teorii ekonomii jest gtębszy niż w gospodarce?, "Ekonomista", No. 2/2014.

Woś R., Więcej państwa proszę!, http://www.obserwatorfinansowy.pl/tematyka/makroekonomia/wiecej-panstwa-prosze (07.10.2015).

Żakowski J. (ed.), Reforma kulturowa 2020-2030-2040. Sukces wymaga zmian, http:// www.kig.pl/files/Aktualnosci/KIG_RAPORT.pdf (07.10.2015). 